\title{
Late Miocene climate and time scale reconciliation: accurate orbital calibration from a deep-sea perspective
}

\author{
Anna Joy Drury ${ }^{1}$, Thomas Westerhold ${ }^{1}$, Thomas Frederichs ${ }^{2}$, Jun Tian $^{3}$, Roy \\ Wilkens $^{4}$, James E. T. Channell ${ }^{5}$, Helen Evans ${ }^{6}$, Cédric M. John ${ }^{7}$, Mitch Lyle ${ }^{8}$, \\ Ursula Röhl ${ }^{1}$ \\ ${ }^{1}$ MARUM - Center for Marine Environmental Sciences, University of Bremen, \\ Germany \\ ${ }^{2}$ Faculty 5 Geosciences, University of Bremen, Germany \\ ${ }^{3}$ State Key Laboratory of Marine Geology, Tongji University, China \\ ${ }^{4}$ School of Ocean and Earth Science and Technology (SOEST), University of Hawai $i$ \\ at Manoa, USA \\ ${ }^{5}$ Department of Geological Sciences, University of Florida, USA \\ ${ }^{6}$ International Ocean Discovery Program, Texas A\&M University, USA \\ ${ }^{7}$ Department of Earth Science and Engineering, Imperial College London, UK \\ ${ }^{8}$ College of Earth, Ocean, and Atmospheric Sciences, Oregon State University, USA
}

Corresponding author: Anna Joy Drury (ajdrury@ marum.de) 


\section{Abstract}

Accurate age control of the late Tortonian to early Messinian (8.3-6.0 Ma) is essential to ascertain the origin of the benthic foraminiferal $\delta^{18} \mathrm{O}$ trends and the late Miocene carbon isotope shift (LMCIS), and to examine temporal relationships between the deep-sea, terrasphere and cryosphere. The current Tortonian-Messinian Geological Time Scale (GTS2012) is based on astronomically calibrated Mediterranean sections; however, no comparable non-Mediterranean stratigraphies exist for 8-6 Ma suitable for testing the GTS2012. Here, we present the first highresolution, astronomically tuned benthic stable isotope stratigraphy (1.5 kyr resolution) and magnetostratigraphy from a single deep-sea location (IODP Site U1337, equatorial Pacific Ocean), which provides unprecedented insight into climate evolution from 8.3-6.0 Ma. The astronomically calibrated magnetostratigraphy provides robust ages, which differ by 2-50 kyr relative to the GTS2012, for polarity Chrons C3An.1n to C4r.1r, and eliminates the exceptionally high South Atlantic spreading rates based on the GTS2012 during Chron C3Bn. We show that the LMCIS was globally synchronous within $2 \mathrm{kyr}$ and provide astronomically calibrated ages anchored to the GPTS for its onset $(7.537 \mathrm{Ma} ; 50 \%$ from base Chron C4n.1n) and termination (6.727 Ma; $11 \%$ from base Chron C3An.2n), confirming that the terrestrial $\mathrm{C} 3: \mathrm{C} 4$ shift could not have driven the LMCIS. The benthic records show that the transition into the 41-kyr world, when obliquity strongly influenced climate variability, already occurred at 7.7 Ma and further strengthened at 6.4 Ma. Previously unseen, distinctive, asymmetric saw-tooth patterns in benthic $\delta^{18} \mathrm{O}$ imply that highlatitude forcing played an important role in late Miocene climate dynamics from 7.76.9 Ma. This new integrated deep-sea stratigraphy from Site U1337 can act as a new stable isotope and magnetic polarity reference section for the 8.3-6.0 Ma interval. 


\section{Introduction}

The late Tortonian to early Messinian (8.3-6.0 Ma) is characterised by longterm reduction in benthic foraminiferal $\delta^{18} \mathrm{O}$ values and by distinctive short-term $\delta^{18} \mathrm{O}$ cycles (Hodell et al., 2001; Drury et al., 2016). Coevally, a permanent -1\%o change in oceanic $\delta^{13} \mathrm{C}_{\text {DIC }}$, referred to as the late Miocene carbon isotope shift (LMCIS), marks the last major global carbon cycle shift expressed in all oceanic basins, after which near-modern inter-oceanic $\delta^{13} \mathrm{C}$ gradients are established at $~ 6.7 \mathrm{Ma}$ (Keigwin, 1979; Hodell and Venz-Curtis, 2006). Furthermore, this time period marks the development of strong equator to pole SST gradients with major cooling at high latitudes but little change in the tropics (Herbert et al., 2016). Accurate age control is crucial to ascertain the origin of the $\delta^{18} \mathrm{O}$ cyclicity and the LMCIS, as constraining the precise timing of such events can allow accurate determination of temporal and causal relationships between deep-sea, terrestrial and cryosphere records.

The late Tortonian - early Messinian Geological Time Scale (GTS2012) is constructed using astronomically tuned sedimentary cycles in Mediterranean successions (Hilgen et al., 1995; Krijgsman et al., 1999). However, recent studies utilising astronomically tuned deep-sea sedimentary successions have challenged the Mediterranean tuning (Channell et al., 2010; Westerhold et al., 2012; Westerhold et al., 2015). Discrepancies in the Mediterranean tuning could originate because road-cut outcrops are often more difficult to integrate and interpret than deep-sea sedimentary successions, which benefit from multiple hole sedimentary splices and integration between multiple sites. To test the Tortonian-Messinian GTS, independent astronomical calibration of Chrons C3An.1n to C4r.1r is required in suitable successions outside the Mediterranean. 
Up to now, no stand-alone integrated high-resolution chemo-, magneto-, and cyclostratigraphy exist for 8-6 Ma from a single non-Mediterranean deep-sea site. The absence of appropriate records was overcome with the retrieval of equatorial Pacific Integrated Ocean Drilling Program (IODP) Site U1337 (Figure 1.A). Site U1337 is an ideal location at which to generate the required stratigraphy, as it is characterised by relatively high pelagic sedimentation rates $(\sim 2 \mathrm{~cm} / \mathrm{kyr})$ and high biogenic carbonate content. Crucially, a rudimentary shipboard magnetic polarity stratigraphy was recovered at Site U1337 with great potential for improvement (Expedition 320/321 Scientists, 2010b).

We present a high-resolution astronomically tuned benthic stable isotope stratigraphy (1.5-2 kyr resolution) and magnetostratigraphy (2.5 kyr resolution across reversals) for 8.3-6.0 Ma to provide accurate age control and constrain late Miocene climate evolution at an unprecedented resolution from a deep-sea perspective. We verify the Site U1337 astrochronology by comparison to an extended benthic stable isotope stratigraphy from equatorial Atlantic Ocean Drilling Program (ODP) Site 926 (Figure 1.A), which has an independent astrochronology (Zeeden et al., 2013). The new U1337 astrochronology is used to independently calibrate the high-resolution magnetostratigraphy and improve the GPTS for 8.3-6.0 Ma and to establish a key reference stratigraphy for the late Miocene. We finally investigate the origin of the LMCIS and the late Tortonian-early Messinian patterns in benthic $\delta^{18} \mathrm{O}$.

\section{Materials and Methods}

All datasets are archived as supplementary tables in the open access Pangaea database (https://doi.pangaea.de/10.1594/PANGAEA.872722). 


\subsection{Site locations and sampling strategy}

This study utilises late Miocene sediments recovered from IODP Site U1337 (Figure 1.A; $3^{\circ} 50.009^{\prime} \mathrm{N}, 123^{\circ} 12.352^{\prime} \mathrm{W} ; 4463 \mathrm{~m}$ water depth; 4190-4260 m palaeowater depth between 8.3-6.0 Ma; Expedition 320/321 Scientists, 2010b; Pälike et al., 2012)) in the eastern equatorial Pacific, retrieved during Pacific Equatorial Age Transect (PEAT) Expedition 321 (Expedition 320/321 Scientists, 2010b). A total of 1186 samples were taken for isotope analysis between 110 and 168.03 revised m composite depth (rmcd = CCSF-A from Wilkens et al., 2013) to increase the resolution of existing 10-cm resolution isotopic record produced at IODP Site U1337 by Jun Tian (Tonji University; Tian et al., in prep), in order to obtain a final resolution of $\sim 3-4 \mathrm{~cm}(\sim 1.5-2 \mathrm{kyr})$. For discrete palaeomagnetic analysis, 597 cube samples (standard ODP $2 \times 2 \times 2 \mathrm{~cm}=8 \mathrm{cc}$ ) were taken between 92.76 and $167.88 \mathrm{~m} \mathrm{rmcd}$ from parallel holes U1337A, U1337B and U1337D, at a minimum sampling resolution of $50 \mathrm{~cm}(100 \mathrm{kyr})$. Across reversals, sampling resolution was increased to $5 \mathrm{~cm}(2.5$ kyr) and completed in at least two parallel holes. All off splice data were adjusted to the revised Wilkens et al. (2013) splice using mapping pairs (Supplementary Table 1).

This study additionally uses sediments from ODP Site 926 (Figure 1.A; $3^{\circ} 43.141^{\prime} \mathrm{N}, 42^{\circ} 54.501^{\prime} \mathrm{W} ; 3598 \mathrm{~m}$ water depth) in the equatorial Atlantic, retrieved during Ceara Rise ODP Leg 154 (Shipboard Scientific Party, 1995). A total of 449 samples were taken at 5-10 cm resolution (3-6 kyr) between 165.86 and $208.03 \mathrm{rmcd}$ (Wilkens et al., 2017a) to increase the resolution of published isotope data between 7.3-5.5 Ma (Shackleton and Hall, 1997) and to extend the record to 8.0 Ma.

\subsection{Site U1337 palaeomagnetic data}


To reconstruct the magnetic reversal stratigraphy between C3An.1n and C4r.1r at Site U1337, all discrete cube samples were analysed for natural remanent magnetization (NRM). Palaeomagnetic directions and magnetization intensities were measured on a cryogenic magnetometer (2G Enterprises model $755 \mathrm{HR}$ ) at the Faculty of Geosciences, University of Bremen (Germany). NRM was measured on each sample before applying alternating field demagnetization using peak-field steps of 5, 7.5 and $10 \mathrm{mT}$. After each demagnetization step, magnetization directions and intensities were measured (Supplementary Table 2).

To determine the characteristic remanent magnetization (ChRM; Supplementary Tables 3 and 4), magnetization components were determined from $\mathrm{AF}$ demagnetization of the NRM using the method of Kirschvink (1980), anchoring components to the origin of orthogonal projections. The peak fields for determination of ChRM are generally in the 5-10 mT range. A stable direction (ChRM) could not be found for $2 \%$ of the samples. The maximum angular deviation (MAD) was calculated to quantify the quality of the individual magnetic component directions. MAD values above $15^{\circ}$ are excluded from further interpretation (9\%). MAD values are generally below $10^{\circ}$, with $10 \%$ falling between $10^{\circ}$ and $15^{\circ}$. Approximately $11 \%$ of the measurements have no MAD value, as they are based on fewer than three demagnetization steps. To azimuthally orient the data, the FLEXIT orientation (Expedition 320/321 Scientists, 2010a) was added to the sample declination values. All FLEXIT corrected declinations larger than $270^{\circ}$ were plotted between $-90^{\circ}$ and $0^{\circ}$.

\subsection{Stable isotope analyses}


SEM images show that the benthic foraminiferal preservation is generally good at both sites, and that the foraminifera are suitable for isotopic analysis (Figure 1. B and C). From Site U1337, 1-6 translucent C. mundulus specimens $(250-500 \mu \mathrm{m})$ and for Site 926, 3-6 translucent $C$. mundulus or $C$. wuellerstorfi $(250-500 \mu \mathrm{m})$ were analysed for carbon $\left(\delta^{13} \mathrm{C}\right)$ and oxygen $\left(\delta^{18} \mathrm{O}\right)$ isotopes using a Kiel I carbonate preparation device attached to a Finnigan MAT 251 at MARUM (University of Bremen, Germany), with an analytical precision of $0.03 \%$ for $\delta^{13} \mathrm{C}$ and $0.04 \%$ for $\delta^{18} \mathrm{O}$. All results are reported against Vienna Peedee Belemnite (VPDB) using the standard $\delta$ notation (per mille \%o), determined using calibrated in-house standards and NBS-19. All data were corrected to equilibrium using the species-specific constants listed in Supplementary Table 5. No offsets were found between the new $\mathrm{U} 1337 \delta^{13} \mathrm{C}$ and $\delta^{18} \mathrm{O}$ and $926 \delta^{13} \mathrm{C}$ data and the existing records at Sites 926 and U1337 (see Supplementary Information for further details). All raw and corrected isotope data are provided in Supplementary Table 6 .

\section{Results}

\subsection{U1337 magnetostratigraphy}

As mentioned above, magnetizations directions associated with MAD values $>15^{\circ}(9 \%)$ were rejected, and magnetization directions of $2 \%$ of samples are not associated with a MAD value as they could not be adequately determined after the three steps of AF demagnetization. The remaining component inclination and declination values from discrete samples are consistent amongst parallel holes and corroborate the shipboard half-core measurements, despite low coercivity and low natural remanent magnetization intensity $(<0.01$ to $5.74 \mathrm{~mA} / \mathrm{m} ;$ mean $=0.14 \pm 0.45$ $\mathrm{mA} / \mathrm{m}$ ) (Figure 2.D-J). We identify 16 polarity reversals at Site U1337 from the top of 
Chron C3An.1n to the base of Chron C4r.1r, with 10 reversals identified with a precision of $\pm 5 \mathrm{~cm}$ ( $2 \mathrm{kyr}$ ) or less (Table 1$)$. The polarity reversals were selected as the centre point between samples that had clearly identifiable opposite polarities, with the distance between these samples providing an indication of uncertainty in the position of the polarity reversal. Data from all parallel holes were considered when available.

\section{2. $\quad \mathrm{U} 1337$ and 926 benthic isotope stratigraphies}

The Site $\mathrm{U} 1337 \delta^{13} \mathrm{C}$ and $\delta^{18} \mathrm{O}$ records are the first records available for the 8-6 Ma interval with $\sim 1.5 \mathrm{kyr}$ sampling resolution (Figure 2.B and C). The U1337 $\delta^{18} \mathrm{O}$ stratigraphy shows the characteristic long-term $0.1-0.2 \%$ late Miocene variations, and $\sim 0.8 \mathrm{~m}$ cycles are observed throughout the record. In the lower part $(\sim 155-135 \mathrm{~m}$ $\mathrm{CCSF}$ ), the new records show well-expressed, short-term $\sim 0.8 \mathrm{~m}$ cycles, with $\delta^{18} \mathrm{O}$ changing by $\sim 0.6 \%$. The new data reveal a saw-tooth pattern not previously resolved (Figure 2.B). The $\mathrm{U} 1337 \delta^{13} \mathrm{C}$ stratigraphy is dominated by a long-term negative $-1 \%$ shift, globally recognised as the LMCIS. Cycles of $\sim 2-2.5 \mathrm{~m}$ dominate the $\delta^{13} \mathrm{C}$ record directly before and after the LMCIS. Weak $\sim 0.8 \mathrm{~m}$ cycles appear in the $\delta^{13} \mathrm{C}$ record during the shift, before replacing the $2-2.5 \mathrm{~m}$ cycles as the dominant cyclicity in the youngest part of the record (Figure 2.C). The $\delta^{18} \mathrm{O}$ and $\delta^{13} \mathrm{C}$ records generally display an antiphase relationship throughout the record, particularly on the scale of $\sim 0.8 \mathrm{~m}$ cycles. This relationship is weak below $120 \mathrm{mcd}$, but becomes stronger at the top of the record, between 110 and 120 mcd.

The additional $\delta^{13} \mathrm{C}$ data produced at Site 926 agree very well with, and increase the resolution of, the available published data. The new $\delta^{13} \mathrm{C}$ record also extends further back in time and captures the full extent of the LMCIS (Figure 3). 


\section{Astrochronology}

\subsection{Minimal and Fine tuning}

Initial age control is provided by a $5^{\text {th }}$ order polynomial fit through 6 shipboard nannofossil datums (Supplementary Table 7). The $\sim 0.8 \mathrm{~m}$ cycles observed throughout the $\delta^{18} \mathrm{O}$ and $\delta^{13} \mathrm{C}$ records are consistent with obliquity forcing, which supports that the record is suitable for orbital tuning. Additionally, the 2-2.5 m cycles observed most strongly in the $\delta^{13} \mathrm{C}$ record correspond to eccentricity periods.

To reconstruct an astronomical age model for Site U1337, we correlate the benthic foraminiferal $\delta^{18} \mathrm{O}$ series to computed variations in the Earth's orbit (Laskar et al., 2004), as the benthic foraminiferal $\delta^{18} \mathrm{O}$ in particular shows strong variability, apparently driven by obliquity. We constructed a tuning target composed of equally weighted eccentricity, tilt and Northern Hemisphere precession (E+T-P, from Laskar et al., 2004), as this combination best represented the interference patterns between obliquity and precession observed in the benthic $\delta^{18} \mathrm{O}$ record, in particular between 6.9 and 7.7 Ma. No phase shift was applied to our tuning to account for possible lags between $\delta^{18} \mathrm{O}$ and insolation forcing due to the response time of ice sheets. Although this has been well established for the Pleistocene (obliquity $=8 \mathrm{kyr}$; precession $=5$ kyr; Imbrie et al., 1984), the response time during the Miocene is unknown (Holbourn et al., 2007). To obtain a minimum tuning, we correlated $\delta^{18} \mathrm{O}$ minima to E+T-P maxima using 17 tie points, following a similar strategy to Holbourn et al. (2007) (Supplementary Table 8). We restricted the correlation to approximately one tie point per $\sim 100$ kyr cycle, as recommended by Zeeden et al. (2015) in order to ensure that no frequency modulation was introduced by the astronomical tuning process. As the purpose of this study is to astronomically calibrate the magnetostratigraphy between 
8.3-6 Ma, a high-resolution, or fine-tuned astrochronology was also generated to reduce the uncertainty in calibration of the reversals. In the fine-tuning strategy, an additional 35 tie points were added between the E+T-P maxima and $\delta^{18} \mathrm{O}$ minima (Figure 4; Supplementary Table 8). Between the minimal and fine-tuned calibrations, the age for each individual isotope point generally changes by $<5 \mathrm{kyr}$, up to a maximum of $12 \mathrm{kyr}$.

\subsection{Validation and revision at Ceara Rise}

The long-term (Myr) and short-term (20-40 kyr) agreement between the $\delta^{13} \mathrm{C}$ records from Sites U1337 (Pacific) and 926 (Atlantic) is excellent (Figure 5.A). This suggests that both astrochronologies are accurate, even though they were generated independently using different proxies: Site U1337: $\delta^{18} \mathrm{O}$ tuned to ET-P with no phase lag; Site 926: magnetic susceptibility and grey scale tuned to P-0.5T with no phase lag (Zeeden et al., 2013; updated in Wilkens et al., 2017). Uncertainty in the correct phase of precession of the tuning target can result in a $10 \mathrm{kyr}$ uncertainty; however, the phase relationship at Ceara Rise has been well-established (see Shackleton and Crowhurst, 1997; Zeeden et al., 2013). The excellent agreement between the $\delta^{13} \mathrm{C}$ records from U1337 and 926 provides further confidence in the choice of a Northern Hemisphere precession in the tuning target of U1337.

The only exception to the excellent agreement in short-term variations is a $20-\mathrm{kyr}$ offset that occurs between the $\delta^{13} \mathrm{C}$ records from 7.7-7.3 Ma, where the Site $926 \delta^{13} \mathrm{C}$ record is 20-kyr older than identical $\delta^{13} \mathrm{C}$ variations at Site U1337 (Figure 5.B). A 20kyr offset between the Atlantic and Pacific oceans cannot be attributed to oceanic circulation processes. It is most likely that the $\delta^{13} \mathrm{C}$ variations are synchronous and this offset reflects an age model inaccuracy. Between 7.7-7.3 Ma, the tuning at Site 
$\mathrm{U} 1337$ is particularly accurate, as the highly distinctive obliquity driven $\delta^{18} \mathrm{O}$ cycles agree extremely well with the E+T-P tuning target (Figure 5.C). However, the offset occurs during a 2.4 Myr eccentricity minimum (Figure 6.E), which implies that the 926 astrochronology is less reliable because the cycles in magnetic susceptibility (MS) and lightness $\left(1^{*}\right)$ are correlated to precession and modulated by eccentricity. During an eccentricity minimum, the modulation of precession is weaker and as a result, the sedimentary cycles are less well expressed. During the $2.4 \mathrm{Myr}$ eccentricity minimum, the 926 astrochronology is therefore adjusted by $20-\mathrm{kyr}$ between 7.76 and 7.30 Ma (Supplementary Table 9). The validity of adjusting the 926 astrochronology by a single precession cycle is supported by a consistent 20-kyr offset between U1337 and $926 \delta^{13} \mathrm{C}$ records, and the excellent agreement between the two records after the uniform adjustment (Figure 5.D).

\section{GPTS calibration and implications for the Fish Canyon standard}

\subsection{GPTS calibration and reconciliation of South Atlantic spreading rates}

We identify 16 polarity reversals at Site U1337 between Chrons C3r and C4r.1r, providing the first complete high-resolution deep-sea polarity stratigraphy from 8.35.2 Ma at a single location (Table 1). The 15 reversals between Chron C3An. $1 \mathrm{n}$ to the base of Chron C4r.1r are astronomically calibrated using the minimal- and fine-tuning calibrations (Figure 6). The age uncertainties, associated with the depth uncertainties in the exact positions of the polarity reversals, are 1-2 kyr for 10 reversals, and 3-5 kyr for the remaining five reversals. The astronomically calibrated reversal ages generally differ by less than $7 \mathrm{kyr}$ between the minimal and fine-tuned age models (Table 1). Considering the low uncertainty in the new U1337 magnetostratigraphy 
and the distinctive $\delta^{18} \mathrm{O}$ and $\delta^{13} \mathrm{C}$ data, this new integrated deep-sea stratigraphy provides a new stable isotope and polarity reference section for the 8.3-6 Ma interval.

The fine-tuned U1337 reversal ages differ by 2-50 kyr relative to the GTS2012 (Table 1). These offsets could originate from: 1) constant offsets due to phase shift and lock-in depth differences or 2) inaccuracies in the magnetostratigraphy or tuning at Site U1337 and/or the Mediterranean sections. No phase shift was applied to either the U1337 or Mediterranean tunings. However, adding a constant phase shift cannot explain the variable offsets of the U1337 calibration to the GTS2012. A finite lock-in depth, the depth below the sediment surface where the sediment magnetisation was acquired (Langereis et al., 2010), could cause an offset of several kyr in reversal ages towards older values, particularly as the mean sedimentation rate $(\sim 2 \mathrm{~cm} / \mathrm{kyr})$ at U1337 is low compared to the Faneromeni section ( $\sim 5 \mathrm{~cm} / \mathrm{kyr}$; Hilgen et al., 1995).

Erroneous magnetostratigraphies and/or astrochronologies are the more likely origin for major $>10 \mathrm{kyr}$ offsets. The U1337 reversals, however, have low depth uncertainties (corresponding to 1-2 kyr for most reversals) and are consistent across parallel holes. In contrast, four reversals within the Mediterranean composite section, consisting of 7 successions, have uncertainties $\geq 10$ kyr (Hilgen et al., 1995, 2000, 2012; Krijgsman et al., 1999). Additionally, the Site U1337 magnetostratigraphy is the only continuous record resolving all polarity chrons from 8-6 Ma. The accuracy of the Site U1337 astrochronology is supported by the remarkable long- and short-term agreement between the Sites U1337 (Pacific) and 926 (Atlantic) $\delta^{13} \mathrm{C}$ records (Fig. 2.B), which were independently tuned using different proxies.

Four U1337 reversal ages remain offset from the GTS2012 after considering the uncertainties in both magnetostratigraphies and the Site U1337 fine-tuned astrochronology: C3An.1r/C3An.2n (50 kyr younger), C3Ar/C3Bn (36 kyr younger), 
C3Br.1n/C3Br.2r (20 kyr older) and C4n.2n/C4r.1r (17 kyr older). The Site U1337 stratigraphy concurs with the H95 timescale (Hilgen et al., 1995) between Chrons C3Bn to C4r.1r but diverges between Chrons C3Ar and the base of C3r, where the H95 ages are older by $30-71 \mathrm{kyr}$, and agreement with the GTS2012 is also poor. The U1337 age of $\mathrm{C} 3 \mathrm{Ar} / \mathrm{C} 3 \mathrm{Bn}$, in particular, is 40 kyr younger than the GTS2012 $\mathrm{C} 3 \mathrm{Ar} / \mathrm{C} 3 \mathrm{Bn}$ reversal age of $7.140 \mathrm{Ma}$ identified at the Mediterranean Oued Akrech section (Hilgen et al., 2000). In the Mediterranean, the C3Ar/C3Bn reversal is clearly identified at Metochia between sapropels M76 and M77 (Krijgsman et al., 1995), 10-20 kyr above sapropel K16 at Kastelli (Krijgsman et al., 1994; Hilgen et al., 1995) and at the top of sapropel OA19 at Oued Akrech (Hilgen et al., 2000). However, sapropels M76/K16 and M77 respectively correlate to sapropel OA20 and OA21 (Hilgen et al., 2000). This correlation results in a 1-2 sapropel/precession cycle difference in the location of $\mathrm{C} 3 \mathrm{Ar} / \mathrm{C} 3 \mathrm{Bn}$ between Metochia/Kastelli and Oued Akrech. The Site U1337 C3Ar/C3Bn reversal age of $7.104 \pm 0.002$ Ma agrees exceptionally well with the $\mathrm{C} 3 \mathrm{Ar} / \mathrm{C} 3 \mathrm{Bn}$ age of $7.101 \pm 0.007$ Ma determined by Hilgen et al. (1995) at Kastelli, which implies that the Oued Akrech age is potentially 40 kyr too old.

Changes in seafloor spreading rates of the South Atlantic spreading centre (e.g. Ogg, 2012; Westerhold et al., 2012) show that spreading rates based on the GTS2012 are the highest of the Cenozoic during Chron C3Bn (Westerhold et al., 2012) (Figure 7.A). The astronomically calibrated magnetostratigraphy from Site U1337 eliminates the high peak during Chron C3Bn and corroborates the rates based on H95 (Figure 7.B). We suggest that the correlation of Oued Akrech to the other Mediterranean successions and to the insolation target could be too old by two precession cycles. This is supported by the reconciliation of spreading rates and 40-kyr offset in the 
$\mathrm{C} 3 \mathrm{Ar} / \mathrm{C} 3 \mathrm{Bn}$ reversal age and due to the consistency between the $\mathrm{C} 3 \mathrm{Ar} / \mathrm{C} 3 \mathrm{Bn}$ reversal ages from Kastelli, Methochia and U1337. A 40-kyr misalignment at Oued Akrech is feasible, as the sapropels at this succession are less well expressed and thicker than the sapropels at the Cretan sections.

\subsection{Implications for the 'Rock-Clock' and Fish Canyon sanadine calibration}

The Mediterranean sections that form the GTS2012 were additionally used in the 'Rock-Clock' synchronisation of ${ }^{40} \mathrm{Ar} /{ }^{39} \mathrm{Ar}$ and $\mathrm{U} / \mathrm{Pb}$, which adjusted the Fish Canyon sanidine (FC) ${ }^{40} \mathrm{Ar} /{ }^{39} \mathrm{Ar}$-dating standard to $28.201 \pm 0.046 \mathrm{Ma}$ (Kuiper et al., 2008). This FC standard age was later refined to $28.173 \pm 0.028 \mathrm{Ma}$ using the astronomically tuned A1 ash layer in the Faneromeni Section on Crete, located in geomagnetic Chron C3Ar (Rivera et al., 2011). However, studies on astronomically tuned deep-sea sedimentary successions have instead proposed a younger FC standard age, challenging the Mediterranean tuning and the 'Rock-Clock' synchronisation (Channell et al., 2010; Westerhold et al., 2012; Westerhold et al., 2015).

The U1337 fine-tuned reversal ages for C3An.2n/C3Ar and C3Ar/C3Bn are used to test the A1 ash layer age. Using inferred sedimentation rates of $4.91 \pm 0.29 \mathrm{~cm} / \mathrm{kyr}$ at Faneromeni and a duration of $0.377 \pm 0.002 \mathrm{Myr}$ for Chron C3Ar from U1337, the A1 age ( 49\% from base of Chron C3Ar) becomes $\sim 6.921 \pm 0.011 \mathrm{Ma}$, which is $\sim 20$ kyr younger than the $6.943 \pm 0.005 \mathrm{Ma}$ age used to verify the 'rock-clock synchronization' (Rivera et al., 2011), although the ages are close considering their respective uncertainties. Although an uncertainty in the precession phase of the U1337 tuning target could add an additional 10 kyr uncertainty, bringing the two A1 ash estimates within error, the C3Ar Chron coincides with an interval where a 
characteristic interference pattern is observed in the benthic $\delta^{18} \mathrm{O}$ between obliquity and precession. The similarity of this interference pattern between the E+T-P tuning target and the $\delta^{18} \mathrm{O}$ record strongly support the use of Northern Hemisphere precession. Additionally, the use of Southern Hemisphere precession could change the anti-phase relationship between benthic $\delta^{18} \mathrm{O}$ and obliquity. We therefore consider the uncertainty due to unknown precession phase as minimal during this interval.

An A1 ash age of 6.921 Ma translates to an FC standard age of $28.083 \pm 0.045$ Ma, which is close to the FC age estimate of 28.10 Ma based on tuned Eocene sections (Westerhold et al., 2015) and is between the older (Kuiper et al., 2008; Rivera et al., 2011) and younger (Channell et al., 2010; Westerhold et al., 2012) FC ages. An FC age of $28.083 \mathrm{Ma}$ increases the offset between $\mathrm{U}-\mathrm{Pb}$ and ${ }^{40} \mathrm{Ar} /{ }^{39} \mathrm{Ar}$ dating and contradicts the 'rock-clock synchronization' of Kuiper et al. (2008). U-Pb and ${ }^{40} \mathrm{Ar} /{ }^{39} \mathrm{Ar}$ ages of coal beds adjacent to the K-Pg boundary are within error when using an FC age of 28.294 Ma (Renne et al., 2013); however, an FC age of 28.083 Ma makes the ${ }^{40} \mathrm{Ar} /{ }^{39} \mathrm{Ar}$ ages $\sim 485 \mathrm{kyr}$ younger than the U-Pb ages. Additionally, the new FC age of 28.083 Ma contradicts the FC eruption age of $28.196 \pm 0.038$ Ma based on $\mathrm{U}-\mathrm{Pb}$ dates from single zircon crystals (Wotzlaw et al., 2013). Thus, our 28.083 Ma estimate could corroborate that a systematic offset exists towards younger ages for ${ }^{40} \mathrm{Ar} /{ }^{39} \mathrm{Ar}$ dating compared to U-Pb dating (Min et al., 2000; Schoene et al., 2006) and supports that the Fish Canyon Tuff may not be an ideal high-precision ${ }^{40} \mathrm{Ar} /{ }^{39} \mathrm{Ar}$ dating standard (Phillips and Matchan, 2013). More interestingly, our FC age estimate of $28.083 \pm 0.045 \mathrm{Ma}(28.038-28.128 \mathrm{Ma})$ is consistent within error of a recently revised FC age of 28.126 \pm 0.019 Ma (28.107-28.145 Ma) (Phillips et al., 2017), obtained by a new generation of multi-collector mass spectrometers that enable highly accurate ${ }^{40} \mathrm{Ar} /{ }^{39} \mathrm{Ar}$ dating. Taken together, this corroborates the suggestion that the 
best FC dating standard age is 28.10 (Westerhold et al., 2015). However, achieving final integration of astrochronological, magnetostratigraphical and radio-isotopic dating techniques, requires analysis of the section with potential to recover accurate chronologies using all three techniques, which has not yet been achieved.

\section{Dynamic Late Miocene 41-kyr world}

Our high-resolution ( 1.5 kyr) benthic isotope records provide unequalled insight into late Tortonian-early Messinian climate evolution and dynamics from 8.36.0 $\mathrm{Ma}$, in particular into the evolution of the cryosphere and carbon cycle components (Figure 6). A key feature is the transition at 7.7 Ma from a short-term eccentricity dominated world into a persistent 41-kyr obliquity driven climate state, which further strengthens at 6.4 Ma (Figure 6.B, C, I, J and K). The 7.7 Ma transition marks a clear shift from dominant 100-kyr cyclicity to dominant 41-kyr cyclicity in the $\delta^{18} \mathrm{O}$ record (Figure 6.I), expressed as clear and distinctive saw-tooth obliquity driven cycles from 7.7-6.9 Ma (Figure 6.C). Between 7.7 and 6.9 Ma, the distinctive $\delta^{18} \mathrm{O}$ cycles display varying degrees of asymmetry (Figure 8). The asymmetry in the $\delta^{18} \mathrm{O}$ record reflects the shape of the ET-P curve, which could indicate that the asymmetry results from the interference pattern between strong obliquity forcing and a minor precessional influence, particularly after 7.2 Ma (Figure 8.B). The 7.7 Ma transition is poorly manifested in benthic $\delta^{13} \mathrm{C}$, as only minor obliquity cyclicity emerges (Figure 6.B and J). This weak $\delta^{18} \mathrm{O}-\delta^{13} \mathrm{C}$ coupling (Figure 6.K) is attributed to a limited cryosphere-carbon cycle interaction, associated with the driving mechanism of the LMCIS (Drury et al., 2016).

Unlike earlier records where short-term transitions from 100-41-100 kyr forcing are observed (Holbourn et al., 2013), the 7.7 Ma transition is the first time that 
the climate system does not return to a 100-kyr dominated world observed in the early and mid Miocene (Holbourn et al., 2013), even when signs of 100-kyr cyclicity return at $~ 7.2 \mathrm{Ma}$ (Figure 6.I). Even during the node in obliquity around 6.5 Ma (Figure 6.E), the $\delta^{18} \mathrm{O}$ record still shows evidence of a response to obliquity forcing, with the observed pattern in $\delta^{18} \mathrm{O}$ values reflecting the interaction between $100-\mathrm{kyr}$ and $41-\mathrm{kyr}$ forcing on the benthic $\delta^{18} \mathrm{O}$ record (Figure 6.C and I). For the first time in this interval, strong obliquity cycles appear at $6.4 \mathrm{Ma}$ in the $\delta^{13} \mathrm{C}$ record, as well as the $\delta^{18} \mathrm{O}$ record, implying a strong cryosphere-carbon cycle coupling and an intensification of the 41kyr beat (Figure 6. B, C, I, J and K). The 7.7 Ma transition and later 6.4 Ma intensification mark the first establishment of a 41-kyr world, which remains a prominent beat in benthic $\delta^{18} \mathrm{O}$ and $\delta^{13} \mathrm{C}$ records for the remainder of the Miocene and into the Plio-Pleistocene (Shackleton and Hall, 1997; Hodell et al., 2001).

\subsection{Implications for glaciations}

The 7.7 Ma transition marks a long-term $-0.2 \%$ shift in $\delta^{18} \mathrm{O}$ between 7.7 and 6.9 Ma, with exceptional 41-kyr-paced saw-tooth $0.6 \%{ }^{18} \mathrm{O}$ cycles superimposed (Figure 6.B). Similar cyclic behaviour, interpreted as dynamic ice volume oscillation (Hodell et al., 2001; Drury et al., 2016), could not be confirmed as high-latitude forcing due to scarce late Miocene proximal ice records (Monien et al., 2012). For the first time for the late Miocene, the unprecedented high-resolution U1337 records show that the short-term $\delta^{18} \mathrm{O}$ variations are distinctive asymmetrical, saw-tooth cycles (slow ice build-up, rapid deglaciation), which are more pronounced than in other records (Figure 8.B). Past studies revealing asymmetrical cycles in the mid-late Miocene have associated this with glacial-interglacial activity (Holbourn et al., 2013). At U1337, though part of the asymmetry may reflect the interaction between 
precessional and obliquity forcing, the combination of the distinctive saw-tooth cycles, the strong obliquity-paced signal and the anti-phase $\delta^{18} \mathrm{O}-\delta^{13} \mathrm{C}$ relationship (characteristic of Pleistocene glacial-interglacial cycles; Broecker and Peng, 1986), all strongly imply that high-latitude climate processes, including ice volume change, drive these cycles between 7.7 and 6.9 Ma (Figure 6.B and C). Coupled with the lower average $\delta^{18} \mathrm{O}$ across this same interval, it could indicate that warming and reduced global ice volume lead to increased dynamic variability and instability in high-latitude regions.

Evidence for high-latitude Northern and Southern Hemisphere ice variation is sparse for the late Tortonian-early Messinian, due to scarce retrieval of sediments that recover this interval (Monien et al., 2012). In addition, bottom water temperature (BWT) estimates for the late Miocene are sparse and severely limited in resolution (Billups and Schrag, 2003; Lear et al., 2003), and cannot resolve temperature changes on the scale of the benthic $\delta^{18} \mathrm{O}$ oscillations. However, Pacific low-resolution $\mathrm{Mg} / \mathrm{Ca}$ records indicate that BWT may have changed by a maximum range of $\sim 1-1.5^{\circ} \mathrm{C}$ (Lear et al., 2003) during the 7.7-6.9 Ma interval. Assuming that half the $0.6 \% \delta^{18} \mathrm{O}$ excursions reflect BTW changes, 0.3\% can be attributed to changes in ice volume, equivalent to $\sim 25 \mathrm{~m}$ of sea level change (using the average early-middle Miocene relationship of $1.2 \% / 100 \mathrm{~m}$ - Gasson et al., 2016). Sea level changes of $\sim 25 \mathrm{~m}$ could reflect considerable variations in small-scale Greenland ice sheets, the Western Antarctic Ice Sheet or East Antarctic subglacial basins, although variations in the Antarctic Ice Sheet are perhaps more realistic considering the warm Northern Hemisphere temperatures observed during the late Miocene (Herbert et al., 2016). However, without verification from ice-proximal records, the true extent of these variations cannot be confirmed. 
The $7.7 \mathrm{Ma}$ climate transition and $0.2 \%$ decrease in average $\delta^{18} \mathrm{O}$ occur when a long 2.4 Myr eccentricity minimum coincides with strong obliquity (Figure 6.D and E), which could explain the increased influence of obliquity and increased highlatitude climate variability. Although eccentricity influence returns at 7.3-7.2 Ma, the sensitivity to obliquity remains strong until $6.9 \mathrm{Ma}$, shortly after a $0.2 \%$ increase in average $\delta^{18} \mathrm{O}$ between 7.0 and 6.9 Ma. However, even during the nodes in obliquity forcing around 6.5 Ma, the system does not return to a strong 100-kyr beat. Why the climate system loses sensitivity to the influence of eccentricity after 7.7 Ma is unclear. No large $\mathrm{CO}_{2}$ changes are visible (Beerling and Royer, 2011) that could drive this sensitivity change and a major long-term cooling in sea surface temperature observed most strongly at mid- to high-latitudes occurs $\sim 0.5 \mathrm{Myr}$ after the $7.7 \mathrm{Ma}$ transition (Herbert et al., 2016). The occurrence of the distinctive $\delta^{18} \mathrm{O}$ cycles during an interval of decreased average $\delta^{18} \mathrm{O}$ could indicate increased sensitivity to obliquity forcing due to a combination of increased temperature and reduced ice volume (Drury et al., 2016). However, to finally resolve the effect of high-latitude temperature versus ice volume change, complimentary high-resolution records of deep-sea temperatures are required.

\subsection{Short-term synchronous onset of the LMCIS}

We provide the first tuned ages anchored to the GPTS for the onset (7.537 Ma; $50 \%$ from base of Chron C4n.1n) and termination (6.727 Ma; $11 \%$ from base of Chron C3An.2n) of the LMCIS (Figure 6.B). The comparison between the U1337 and ODP $926 \delta^{13} \mathrm{C}$ records shows that the onset and termination of the LMCIS occurred within $<2$ kyr between the Atlantic and the Pacific (Figure 4). The origin of the LMCIS is unknown; however, anchoring the shift to the GPTS facilitates comparison 
with terrestrial records of the $\mathrm{C} 3: \mathrm{C} 4$ vegetation shift, which has been proposed as a mechanism for changing the continental carbon flux into the ocean (Bickert et al., 2004). However, the C3:C4 shift is gradual and globally asynchronous (8-4 Ma in Pakistan - Behrensmeyer et al., 2007; 10-0 Ma in eastern Africa - Uno et al., 2016), which makes it an unlikely mechanism to explain the LMCIS, as the onset and end of the shift are synchronous between oceanic basins on short timescales (Figure 6.B). The LMCIS onset was linked to increased terrestrial organic carbon erosion during a sea level drop (Bickert et al., 2004). However, the onset of the LMCIS occurs $\sim 150$ kyr after a $0.2 \%$ benthic $\delta^{18} \mathrm{O}$ reduction at $7.7 \mathrm{Ma}$, which contradicts an increase in global ice volume (Figure 6.C). Additionally, if sea level driven organic matter input controlled the LMCIS, a stronger $\delta^{18} \mathrm{O}-\delta^{13} \mathrm{C}$ coupling would be expected than is observed at Site U1337 and elsewhere (Figure 6.B and C; Drury et al., 2016).

\section{Conclusions}

Our study represents the first complete, high-resolution astronomically calibrated integrated chemo-magnetostratigraphy for the 8.3-6 Ma interval from a single deep-sea location. Astronomical calibration of the Site U1337 magnetostratigraphy eliminates exceptionally high spreading rates in the South Atlantic anomaly profile during Chron $\mathrm{C} 3 \mathrm{Bn}$ and provides robust ages for magnetic reversals $\mathrm{C} 3 \mathrm{r} / \mathrm{C} 3 \mathrm{An} .1 \mathrm{n}$ to $\mathrm{C} 4 \mathrm{r} .1 \mathrm{r} / \mathrm{C} 4 \mathrm{r}$.1n. Comparison of the new magnetochronology with coeval Mediterranean successions suggests that the astronomical calibrated age for the Faneromeni A1 ash layer used for the 'rock-clock synchronization' could be $\sim 20$ kyr younger.

At 7.7 Ma, a transition occurs from an eccentricity-dominated world into a climate state with persistent 41-kyr obliquity-driven beat, which further strengthened 
at $6.4 \mathrm{Ma}$. The previously unseen saw-tooth patterns in the antiphased benthic $\delta^{18} \mathrm{O}$ and $\delta^{13} \mathrm{C}$ data indicate a dominantly high-latitude forcing with dynamic ice sheets from 7.7-6.9 Ma. The distinctive $0.6 \%$ o $\delta^{18} \mathrm{O}$ excursions could indicate $\sim 25 \mathrm{~m}$ of sea level change during this time.

Additionally, for the first time, we provide astronomically calibrated ages anchored to the GPTS for the onset (7.537 Ma; 50\% from base of Chron C4n.1n) and termination (6.727 Ma; $11 \%$ from base of Chron C3An.2n) of the LMCIS. A comparison of astronomically tuned $\delta^{13} \mathrm{C}$ records from the Atlantic and Pacific shows that the LMCIS was synchronous to within $2 \mathrm{kyr}$. This comparison and the anchoring of the LMCIS to the GPTS, confirms that the C3:C4 shift could not have driven the LMCIS.

\section{References}

Backman, J., and Raffi, I., 1997, Calibration of Miocene Nannofossil events to orbitally tuned cyclostratigraphies from Ceara Rise: Proceedings Ocean Drilling Program, Scientific Results, v. 154, p. 83-99.

Beerling, D.J., and Royer, D.L., 2011, Convergent Cenozoic $\mathrm{CO}_{2}$ history: Nature Geoscience, v. 4, no. 7, p. 418-420, doi: 10.1038/ngeo1186.

Behrensmeyer, A.K., Quade, J., Cerling, T.E., Kappelman, J., Khan, I.A., Copeland, P., Roe, L., Hicks, J., Stubblefield, P., Willis, B.J., and Latorre, C., 2007, The structure and rate of late Miocene expansion of C4 plants: Evidence from lateral variation in stable isotopes in paleosols of the Siwalik Group, northern Pakistan: Geological Society of America Bulletin, v. 119, no. 11-12, p. 1486-1505, doi: 10.1130/b26064.1.

Bickert, T., Haug, G.H., and Tiedemann, R., 2004, Late Neogene benthic stable 
isotope record of Ocean Drilling Program Site 999: Implications for Caribbean paleoceanography, organic carbon burial, and the Messinian Salinity Crisis:

Paleoceanography, v. 19, no. 1, doi: 10.1029/2002PA000799.

Billups, K., and Schrag, D.P., 2003, Application of benthic foraminiferal Mg/Ca ratios to questions of Cenozoic climate change: Earth and Planetary Science Letters, v. 209, no. 1-2, p. 181-195, doi: 10.1016/s0012-821x(03)00067-0.

Broecker, W.S., and Peng, T.-H., 1986, Glacial To Interglacial Changes in the Operation of the Global Carbon Cycle: Radiocarbon, v. 28, no. 2, p. 309-327.

Cande, S.C., and Kent, D. V., 1995, Revised calibration of the geomagnetic polarity timescale for the late Cretaceous and Cenozoic: Journal of Geophysical Research-Solid Earth, v. 100, no. B4, p. 6093-6095, doi: 10.1029/94jb03098.

Channell, J.E.T., Hodell, D.A., Singer, B.S., and Xuan, C., 2010, Reconciling astrochronological and ${ }^{40} \mathrm{Ar} /{ }^{39} \mathrm{Ar}$ ages for the Matuyama-Brunhes boundary and late Matuyama Chron: Geochemistry, Geophysics, Geosystems, v. 11, doi: 10.1029/2010GC003203.

Clement, B.M., 2004, Dependence of the duration of geomagnetic polarity reversals on site latitude: Nature, v. 428, no. 6983, p. 637-640.

Drury, A.J., John, C.M., and Shevenell, A.E., 2016, Evaluating climatic response to external radiative forcing during the late Miocene to early Pliocene: New perspectives from eastern equatorial Pacific (IODP U1338) and North Atlantic (ODP 982) locations: Paleoceanography, v. 31, no. 1, p. 167-184, doi: 10.1002/2015PA002881.

Expedition 320/321 Scientists, 2010a, Methods, in Pälike, H., Lyle, M., Nishi, H., Gamage, K., Klaus, A., and Expedition 320/321 Scientists eds., Proceedings of the Integrated Ocean Drilling Program, p. 1-80. 
Expedition 320/321 Scientists, 2010b, Site U1337, in Pälike, H., Lyle, M., Nishi, H., Raffi, I., Gamage, K., Klaus, A., and Scientists, E. 320/321 eds., Proceedings of the Integrated Ocean Drilling Program, Tokyo (Integrated Ocean Drilling Program Management International, Inc.), p. 1-146.

Gasson, E., DeConto, R.M., Pollard, D., and Levy, R.H., 2016, Dynamic Antarctic ice sheet during the early to mid-Miocene: Proceedings of the National Academy of Sciences, , no. 34, p. 201516130, doi: 10.1073/pnas.1516130113.

Grinsted, A., Moore, J.C., and Jevrejeva, S., 2004, Application of the cross wavelet transform and wavelet coherence to geophysical time series: Nonlinear Processes in Geophysics, v. 11, no. 5-6, p. 561-566.

Herbert, T.D., Lawrence, K.T., Tzanova, A., Peterson, L.C., Caballero-Gill, R., and Kelly, C.S., 2016, Late Miocene global cooling and the rise of modern ecosystems: Nature Geosci, v. advance on, no. September 2016, doi: 10.1038/NGEO2813.

Hilgen, F.J., 1991, Extension of the astronomically calibrated (polarity) time scale to the Miocene Pliocene boundary: Earth and Planetary Science Letters, v. 107, no. 2, p. 349-368, doi: 10.1016/0012-821x(91)90082-s.

Hilgen, F.J., Bissoli, L., Iaccarino, S., Krijgsman, W., Meijer, R., Negri, A., and Villa, G., 2000, Integrated stratigraphy and astrochronology of the Messinian GSSP at Oued Akrech (Atlantic Morocco): Earth and Planetary Science Letters, v. 182, no. 3-4, p. 237-251, doi: 10.1016/S0012-821X(00)00247-8.

Hilgen, F.J., Krijgsman, W., Langereis, C.G., Lourens, L.J., Santarelli, A., and Zachariasse, W.J., 1995, Extending the astronomical (polarity) time scale into the Miocene: Earth and Planetary Science Letters, v. 136, p. 495-510, doi: 10.1016/0012-821X(95)00207-S. 
Hilgen, F.J., Lourens, L.J., Van Dam, J.A., Beu, A.G., Boyes, A.F., Cooper, R.A., Krijgsman, W., Ogg, J.G., Piller, W.E., and Wilson, D.S., 2012, Chapter 29 The Neogene Period, in The Geologic Time Scale, p. 923-978.

Hodell, D.A., Curtis, J.H., Sierro, F.J., and Raymo, M.E., 2001, Correlation of late Miocene to early Pliocene sequences between the Mediterranean and North Atlantic: Paleoceanography, v. 16, no. 2, p. 164-178, doi: 10.1029/1999pa000487.

Hodell, D.A., and Venz-Curtis, K.A., 2006, Late Neogene history of deepwater ventilation in the Southern Ocean: Geochemistry Geophysics Geosystems, v. 7, no. 9, p. (Q09001), doi: 10.1029/2005GC001211.

Holbourn, A., Kuhnt, W., Clemens, S., Prell, W., and Andersen, N., 2013, Middle to late Miocene stepwise climate cooling: Evidence from a high-resolution deep water isotope curve spanning 8 million years: Paleoceanography, v. 28, no. 4, p. 688-699, doi: 10.1002/2013PA002538.

Holbourn, A., Kuhnt, W., Schulz, M., Flores, J.A., and Andersen, N., 2007, Orbitallypaced climate evolution during the middle Miocene "Monterey" carbon-isotope excursion: Earth and Planetary Science Letters, v. 261, no. 3-4, p. 534-550, doi: 10.1016/j.eps1.2007.07.026.

Imbrie, J., Hays, J.D., Martinson, D.G., McIntyre, A., Mix, A.C., Morley, J.J., Pisias, N.G., Prell, W.L., and Shackleton, N.J., 1984, The orbital theory of Pleistocene climate: support from a revised chronology of the marine $\delta^{18} \mathrm{O}$ record, in Berger, A., Imbrie, J., Hays, J., Kukla, G., and Saltzman, B. eds., Milankovitch and Climate: Understanding the Response to Astronomical Forcing, p. 269.

Keigwin, L.D., 1979, Late Cenozoic stable isotope stratigraphy and paleoceanography of DSDP sites from the east equatorial and central North Pacific Ocean: Earth 
Confidential manuscript submitted to Earth and Planetary Science Letters

and Planetary Science Letters, v. 45, no. 2, p. 361-382, doi: 10.1215/036168782682650.

Krijgsman, W., Hilgen, F.J., Langereis, C.G., Santarelli, A., and Zachariasse, W.J., 1995, Late Miocene magnetostratigraphy, biostratigraphy and cyclostratigraphy in the Mediterranean: Earth and Planetary Science Letters, v. 136, no. 3, p. 475494, doi: http://dx.doi.org/10.1016/0012-821X(95)00206-R.

Krijgsman, W., Hilgen, F.J., Langereis, C.G., and Zachariasse, W.J., 1994, The Age of the Tortonian Messinian Boundary: Earth and Planetary Science Letters, v. 121, no. 3-4, p. 533-547, doi: 10.1016/0012-821X(94)90089-2.

Krijgsman, W., Hilgen, F.J., Raffi, I., Sierro, F.J., and Wilson, D.S., 1999, Chronology, causes and progression of the Messinian salinity crisis: Nature, v. 400, no. 6745, p. 652-655, doi: 10.1038/23231.

Kuiper, K.F., Deino, A., Hilgen, F.J., Krijgsman, W., Renne, P.R., and Wijbrans, J.R., 2008, Synchronizing Rock Clocks of Earth History: Science, v. 320, no. 5875, p. 500-504, doi: 10.1126/science.1154339.

Langereis, C.G., Krijgsman, W., Muttoni, G., and Menning, M., 2010, Magnetostratigraphy - concepts, definitions, and applications: Newsletters on Stratigraphy, v. 43, no. 3, p. 207-233, doi: 10.1127/0078-0421/2010/0043-0207.

Laskar, J., Robutel, P., Joutel, F., Gastineau, M., Correia, a. C.M., and Levrard, B., 2004, A long-term numerical solution for the insolation quantities of the Earth: Astronomy and Astrophysics, v. 428, no. 1, p. 261-285, doi: 10.1051/00046361:20041335.

Lear, C.H., Rosenthal, Y., and Wright, J.D., 2003, The closing of a seaway: ocean water masses and global climate change: Earth and Planetary Science Letters, v. 210, no. 3-4, p. 425-436, doi: 10.1016/s0012-821x(03)00164-x. 
Lourens, L., Hilgen, F.J., Shackleton, N.J., Laskar, J., and Wilson, D., 2004, The Neogene Period, in Gradstein, F.M., Ogg, J.G., and Smith, A.G. eds., A Geologic Time Scale 2004, Cambridge University Press, p. 409-440.

Min, K., Mundil, R., Renne, P.R., and Ludwig, K.R., 2000, A test for systematic errors in ${ }^{40} \mathrm{Ar} /{ }^{39} \mathrm{Ar}$ geochronology through comparison with $\mathrm{U} / \mathrm{Pb}$ analysis of a 1.1-Ga rhyolite: Geochimica et Cosmochimica Acta., v. 64, no. 1, p. 73-98.

Monien, D., Kuhn, G., von Eynatten, H., and Talarico, F.M., 2012, Geochemical provenance analysis of fine-grained sediment revealing Late Miocene to recent Paleo-Environmental changes in the Western Ross Sea, Antarctica: Global and Planetary Change, v. 96-97, no. 2012, p. 41-58, doi:

10.1016/j.gloplacha.2010.05.001.

Ogg, J.G., 2012, Chapter 5 - Geomagnetic Polarity Time Scale, in The Geologic Time Scale, p. 85-113.

Pälike, H., Lyle, M.W., Nishi, H., Raffi, I., Ridgwell, A., Gamage, K., Klaus, A., Acton, G., Anderson, L., Backman, J., Baldauf, J., Beltran, C., Bohaty, S.M., Bown, P., et al., 2012, A Cenozoic record of the equatorial Pacific carbonate compensation depth: Nature, v. 488, no. 7413, p. 609-614, doi: 10.1038/nature11360.

Phillips, D., and Matchan, E.L., 2013, Ultra-high precision ${ }^{40} \mathrm{Ar} /{ }^{39} \mathrm{Ar}$ ages for Fish Canyon Tuff and Alder Creek Rhyolite sanidine: New dating standards required? Geochimica et Cosmochimica Acta, v. 121, p. 229-239, doi: 10.1016/j.gca.2013.07.003.

Phillips, D., Matchan, E.L., Honda, M., and Kuiper, K.F., 2017, Astronomical calibration of 40Ar/39Ar reference minerals using high-precision, multi-collector (ARGUSVI) mass spectrometry: Geochimica et Cosmochimica Acta, v. 196, no. 
2017, p. 351-369, doi: 10.1016/j.gca.2016.09.027.

Renne, P.R., Deino, A.L., Hilgen, F.J., Kuiper, K.F., Mark, D.F., Mitchell, W.S., Morgan, L.E., Mundil, R., and Smit, J., 2013, Time scales of critical events around the Cretaceous-Paleogene boundary.: Science (New York, N.Y.), v. 339, no. 6120 , p. 684-7, doi: $10.1126 /$ science. 1230492 .

Rivera, T.A., Storey, M., Zeeden, C., Hilgen, F.J., and Kuiper, K., 2011, A refined astronomically calibrated ${ }^{40} \mathrm{Ar} /{ }^{39} \mathrm{Ar}$ age for Fish Canyon sanidine: Earth and Planetary Science Letters, v. 311, no. 3-4, p. 420-426, doi: 10.1016/j.epsl.2011.09.017.

Schoene, B., Crowley, J.L., Condon, D.J., Schmitz, M.D., and Bowring, S.A., 2006, Reassessing the uranium decay constants for geochronology using ID-TIMS UPb data: Geochimica et Cosmochimica Acta, v. 70, no. 2, p. 426-445, doi: 10.1016/j.gca.2005.09.007.

Shackleton, N.J., and Crowhurst, S., 1997, Sediment fluxes based on an orbitally tuned time scale 5 Ma to 14 Ma, Site 926: Proceedings of the Ocean Drilling Program, Scientific Results, v. 154, p. 69-82.

Shackleton, N.J., and Hall, M.A., 1997, The Late Miocene Stable Isotope Record, Site 926, in Shackleton, N.J., Curry, W.B., Richter, C., and Bralower, T.J. eds., Proceedings of the Ocean Drilling Program, Scientific Results, College Station, TX (Ocean Drilling Program), p. 367-373.

Shipboard Scientific Party Leg 154, 1995, Site 926 (W. Curry, N. Shackleton, \& C. Richter, Eds.): Proceedings of the Ocean Drilling Program, Initial Reports, v. 154.

Tian, J., Ma, X., Zhou, J., Lyle, M., and Shackford, J.K. A 16-Myr-long record of benthic foraminiferal $\delta^{18} \mathrm{O}$ and $\delta^{13} \mathrm{C}$ from the eastern equatorial Pacific: to be 
Confidential manuscript submitted to Earth and Planetary Science Letters

submitted to EPSL.

Uno, K.T., Polissar, P.J., Jackson, K.E., and deMenocal, P.B., 2016, Neogene biomarker record of vegetation change in eastern Africa: Proceedings of the National Academy of Sciences, v. 113, no. 23, p. 6355-6363, doi: 10.1073/pnas.1521267113.

Westerhold, T., Röhl, U., Frederichs, T., Bohaty, S.M., and Zachos, J.C., 2015, Astronomical calibration of the geological timescale: Closing the middle Eocene gap: Climate of the Past, v. 11, no. 9, p. 1181-1195, doi: 10.5194/cp-11-11812015.

Westerhold, T., Röhl, U., and Laskar, J., 2012, Time scale controversy: Accurate orbital calibration of the early Paleogene: Geochemistry, Geophysics, Geosystems, v. 13, no. 6, p. 1-19, doi: 10.1029/2012GC004096.

Wilkens, R.H., Dickens, G.R., Tian, J., Backman, J., and Scientists, E. 320/321, 2013, Data report: revised composite depth scales for Sites U1336, U1337, and U1338, in Pälike, H., Lyle, M., Nishi, H., Raffi, I., Gamage, K., Klaus, A., and Scientists, E. 320/321 eds., Proceedings of the Integrated Ocean Drilling Program, Scientific Results, p. 1-158.

Wilkens, R., Westerhold, T., Drury, A.J., Lyle, M., Gorgas, T., and Tian, J., 2017, Revisiting the Ceara Rise, equatorial Atlantic Ocean: isotope stratigraphy of ODP Leg 154: Climate of the Past Discussions, p. 1-22, doi: 10.5194/cp-2016140.

Wotzlaw, J.F., Schaltegger, U., Frick, D.A., Dungan, M.A., Gerdes, A.G., and Günther, D., 2013, Tracking the evolution of large-volume silicic magma reservoirs from assembly to supereruption: Geology, v. 41, no. 8, p. 867-870, doi: 10.1130/G34366.1. 
Zeeden, C., Hilgen, F., Westerhold, T., Lourens, L., Röhl, U., and Bickert, T., 2013, Revised Miocene splice, astronomical tuning and calcareous plankton biochronology of ODP Site 926 between 5 and 14.4 Ma: Palaeogeography, Palaeoclimatology, Palaeoecology, v. 369, p. 430-451, doi: 10.1016/j.palaeo.2012.11.009.

Zeeden, C., Meyers, S.R., Lourens, L.J., and Hilgen, F.J., 2015, Testing astronomically tuned age models: Paleoceanography, v. 30, no. 4, p. 369-383, doi: 10.1002/2014PA002762.

\section{Acknowledgements}

We thank H. Kuhnert and his team (MARUM) for stable isotope analyses, A. Wülbers, W. Hale (IODP Bremen Core Repository) and P. Rumford (IODP Gulf Coast Repository) for core handling, T.E. van Peer for sampling, and B. Donner (MARUM) for providing foraminiferal expertise. This research used samples and data provided by the International Ocean Discovery Program (IODP), sponsored by the US National Science Foundation (NSF) and participating countries. Jun Tian is sponsored by NSFC projects (Grant No. 41525020, 91428310). The Deutsche Forschungsgemeinschaft (DFG) provided financial support for this research (We5479/1). All datasets are archived as supplementary tables in the open access Pangaea database (https://doi.pangaea.de/10.1594/PANGAEA.872722). 


\section{Tables}

Table 1. Astronomically calibrated magnetostratigraphy from Site U1337, compared to CK95, H95 and GTS2004/2012 (Cande and Kent, 1995; Hilgen et al., 1995; Lourens et al., 2004; Hilgen et al., 2012).

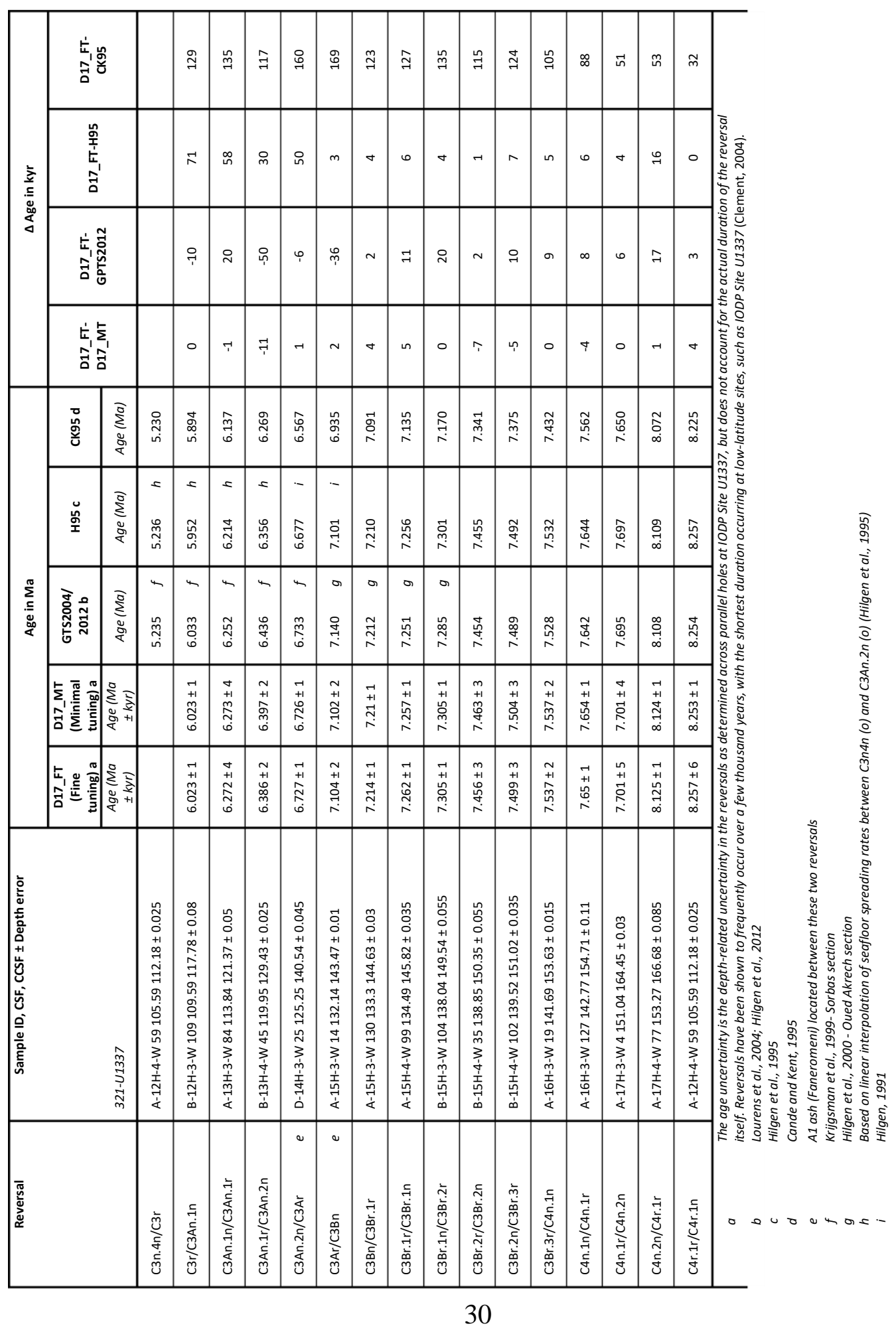




\section{Figures}

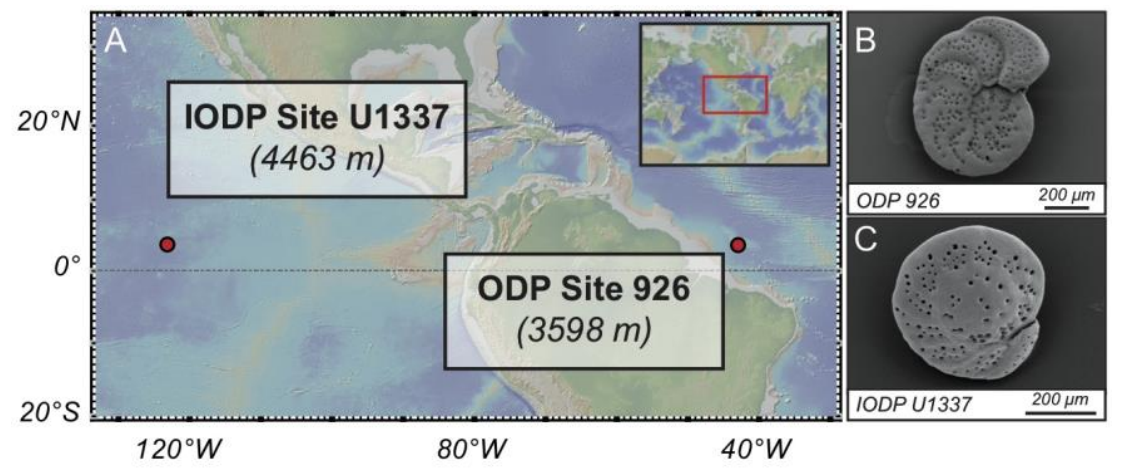

Figure 1. A) Location and water depth of IODP Site U1337 in the equatorial Pacific and Ocean Drilling Program ODP Site 926 on Ceara Rise in the equatorial Atlantic (http://www.geomapapp.org); B) SEM image of a Cibicidoides wuellerstorfi from Site 926; C) SEM image of a Cibicidoides mundulus from Site U1337. 


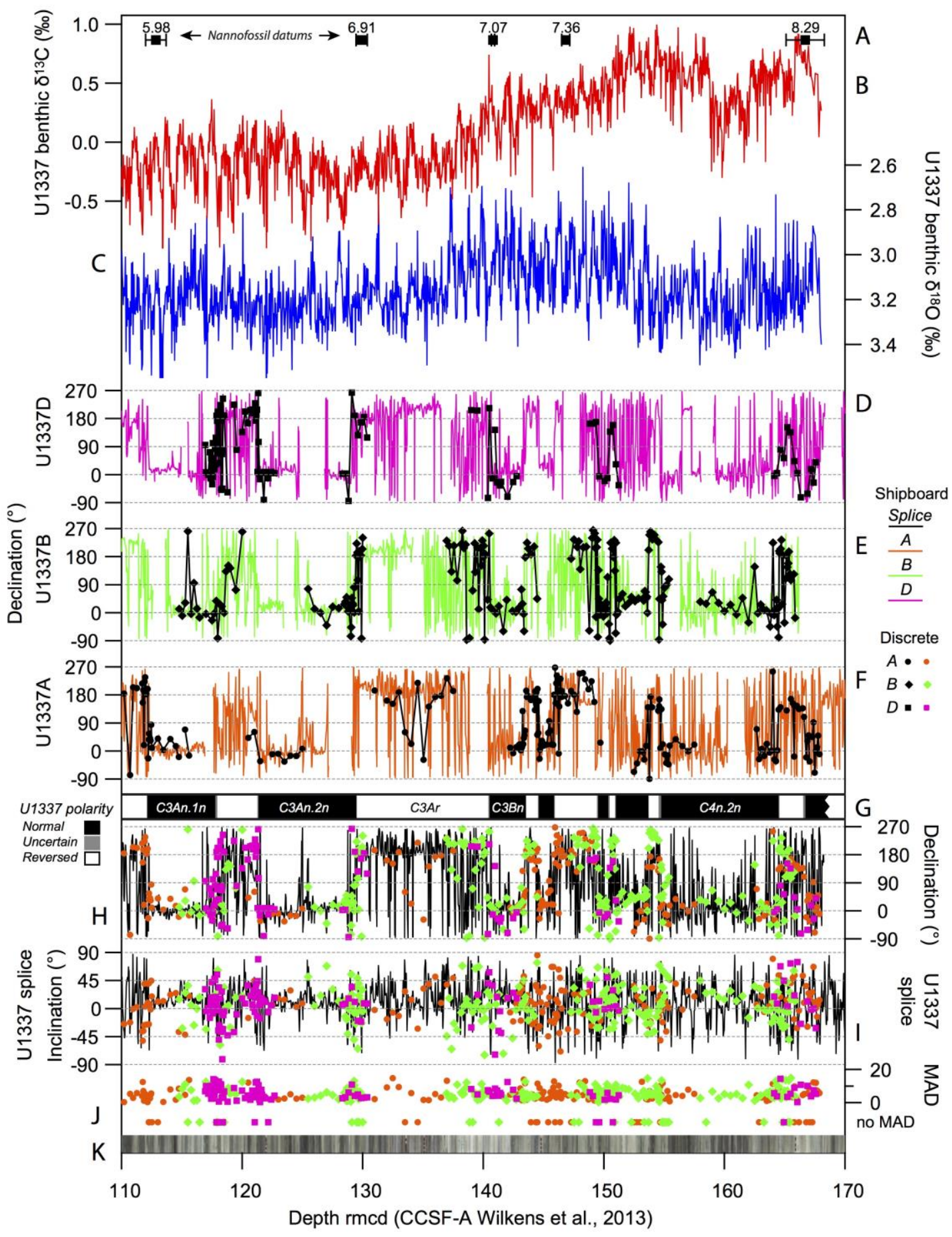

Figure 2. Late Miocene palaeoceanographical records from Site U1337 on depth rmcd (CCSF-A Wilkens et al., 2013). A: Shipboard nannofossil datums (Expedition 320/321 Scientists, 2010b) with the GTS2012 age noted in the label (Hilgen et al., 2012). B: Benthic foraminiferal $\delta^{13} \mathrm{C}$ (in \%o versus VPDB). C: Benthic foraminiferal $\delta^{18} \mathrm{O}$ (in \%o versus VPDB). D: Discrete and shipboard declination data from Hole D. 
E: Discrete and shipboard declination data from Hole B. F: Discrete and shipboard declination data from Hole A. G: Interpreted magnetostratigraphy from Site U1337. H: Splice shipboard declination data with all discrete measurements. I: Splice shipboard inclination data with all discrete measurements. J: Discrete MAD values. $\mathrm{K}$ : Composite core image.

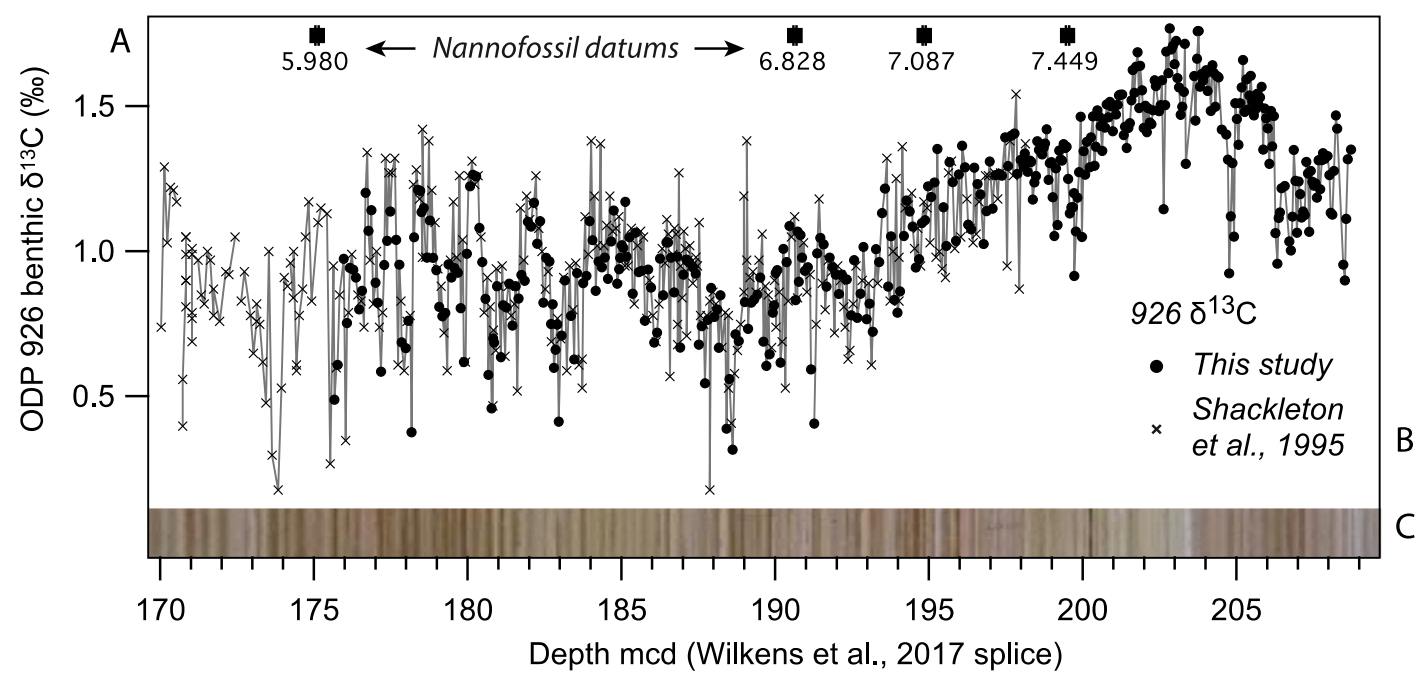

Figure 3. Late Miocene benthic $\delta^{13} \mathrm{C}$ record from Site 926 on depth rmcd (Wilkens et al., 2017). A: Shipboard nannofossil datums in Ma (Backman and Raffi, 1997) with the Zeeden et al. (2013) age noted in the label (with the exception of the age for B Amaurolithus spp. / B Amaurolithus primus, which has been altered to account for the adjustment to the ODP 926 age model). B: Benthic foraminiferal $\delta^{13} \mathrm{C}$ (in \%o versus VPDB). C: Composite core image. 


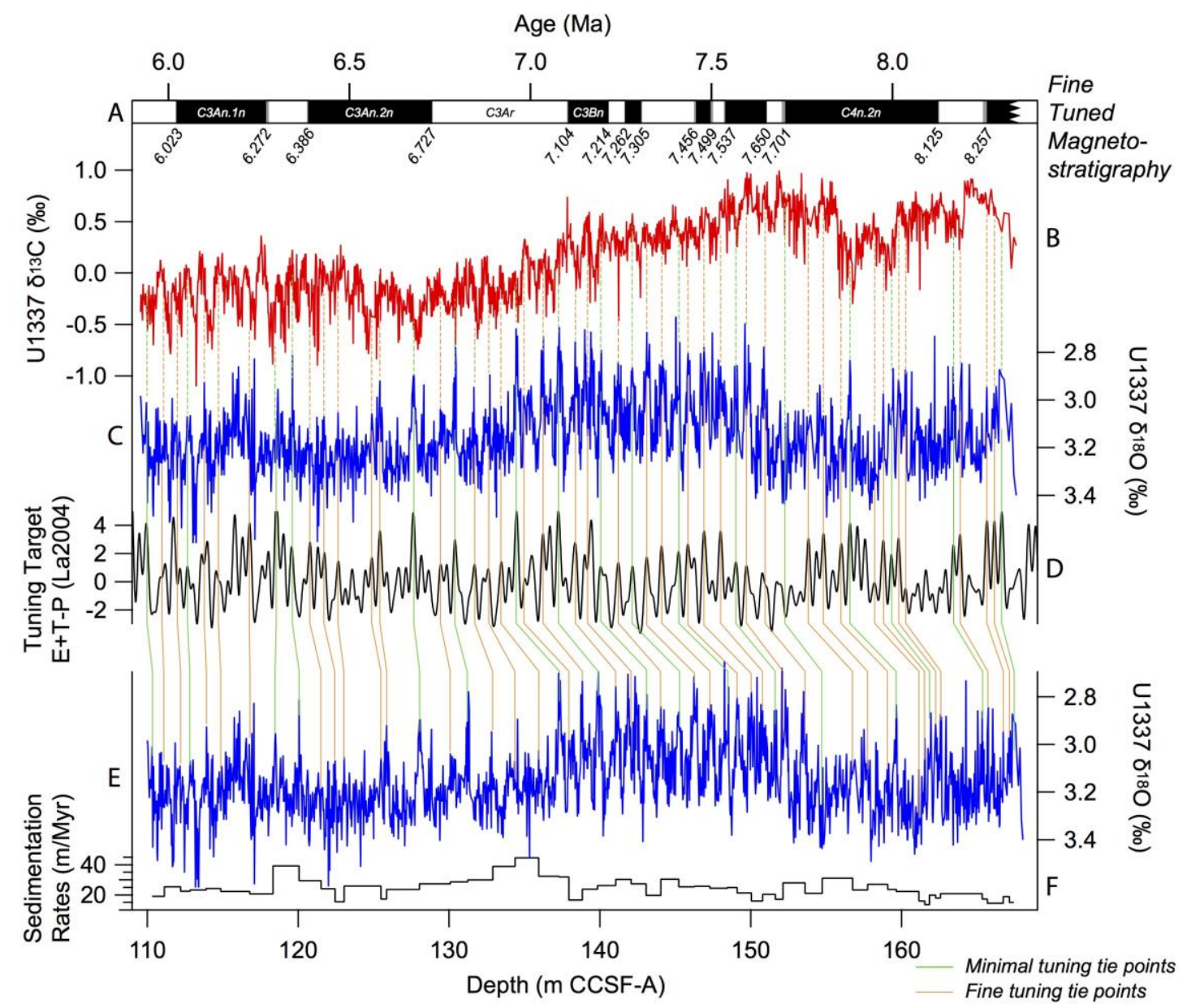

Figure 4. Fine-tuning of the Site U1337 chemo- and magnetostratigraphy, with minimal tuning tie points indicated in green and fine-tuning tie points indicated in orange. A: Fine-tuned magnetostratigraphy from Site U1337. B: Fine-tuned benthic foraminiferal $\delta^{13} \mathrm{C}$ (in \%o versus VPDB). C: Fine-tuned benthic foraminiferal $\delta^{18} \mathrm{O}$ (in \%o versus VPDB). D: Eccentricity+Tilt-Precession tuning target (E+T-P) from Laskar et al. (2004) E: Benthic foraminiferal $\delta^{18} \mathrm{O}$ (in \%o versus VPDB) on depth rmcd Wilkens et al. (2013). F: Fine-tuned sedimentation rates (in m/Myr) on depth rmcd. 

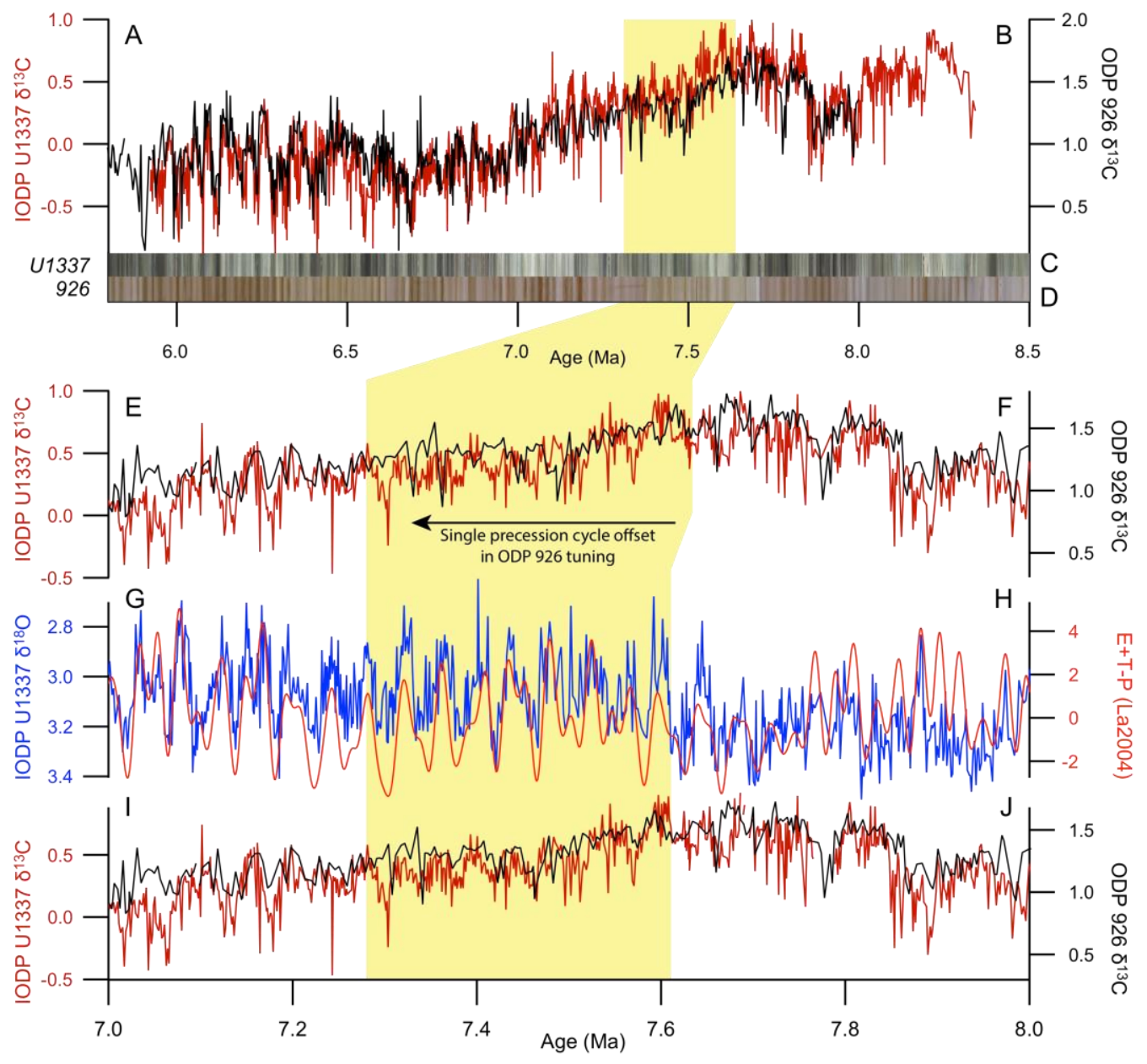

Figure 5. Offset between the fine-tune U1337 and original 926 astrochronologies.

Benthic $\delta^{13} \mathrm{C}$ (in \%o versus VPDB) between 8.5-5.8 Ma from (A) Site U1337 on the

fine-tuned astrochronology and from (B) Site 926 on the Zeeden et al. (2013) chronology. Composite core images from (C) U1337 and (D) 926 . Benthic $\delta^{13} \mathrm{C}$ (in \%o versus VPDB) between 8-7 Ma from (E) Site U1337 on the fine-tuned astrochronology and from (F) Site 926 on the Zeeden et al. (2013) chronology. Benthic $\delta^{18} \mathrm{O}$ (in \%o versus VPDB) between 8-7 Ma from (G) Site U1337 on the finetuned astrochronology and $(\mathrm{H})$ Eccentricity+Tilt-Precession tuning target (E+T-P) from Laskar et al. (2004). Benthic $\delta^{13} \mathrm{C}$ (in \%o versus VPDB) between 8-7 Ma from 
(E) Site U1337 on the fine-tuned astrochronology and from (F) Site 926 on the adjusted astrochronology.

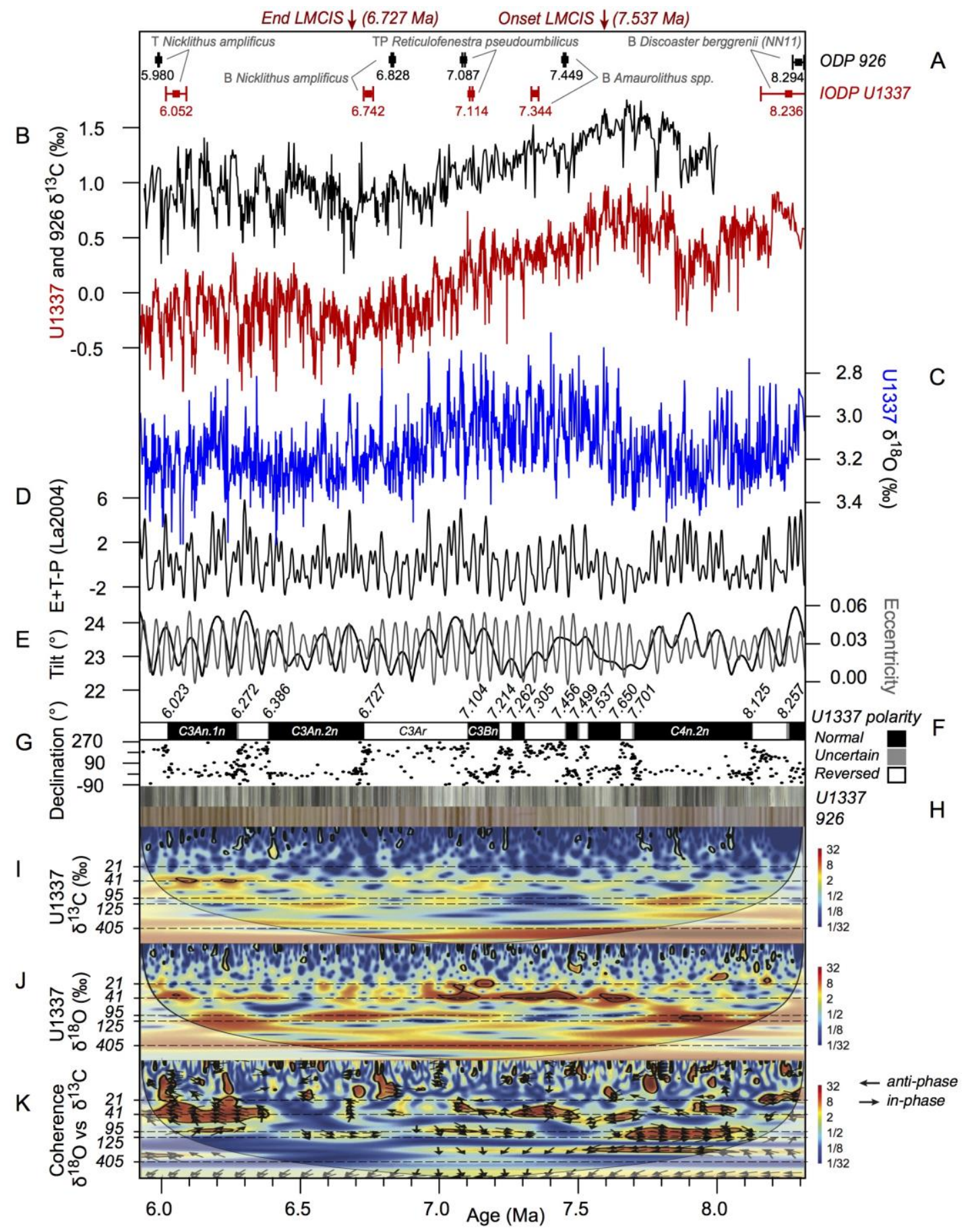

Figure 6. Late Miocene records from IODP Site U1337 and ODP Site 926. The Site U1337 fine-tuned age model was used. A: Astronomically tuned nannofossil datums from U1337 and 926 in Ma. B: U1337 and 926 benthic foraminiferal $\delta^{13} \mathrm{C}$ (in \%o 
versus Vienna Peedee belemnite, VPDB) and the late Miocene carbon isotope shift (LMCIS). C: U1337 benthic foraminiferal $\delta^{18} \mathrm{O}$ (in \%o versus VPDB). D: Eccentricity+Tilt-Precession tuning target (E+T-P) from La2004 (Laskar et al., 2004). E: Eccentricity and Tilt from La2004. F: U1337 astronomically tuned magnetostratigraphy. G: U1337 discrete declination data. H: U1337 and 926 composite core images. I: Wavelet analysis of the Site U1337 benthic $\delta^{18} \mathrm{O}$ data (in \%o versus VPDB) on the fine tuned astrochronology. J: Wavelet analysis of the Site U1337 benthic $\delta^{13} \mathrm{C}$ data (in \%o versus VPDB) on the fine tuned astrochronology. K: Coherence wavelet analysis of the Site U1337 benthic $\delta^{18} \mathrm{O}$ and $\delta^{13} \mathrm{C}$ data (in \%o versus VPDB) on the fine tuned astrochronology. Wavelet analyses were produced using the Matlab code provided by Grinsted et al. (2004).

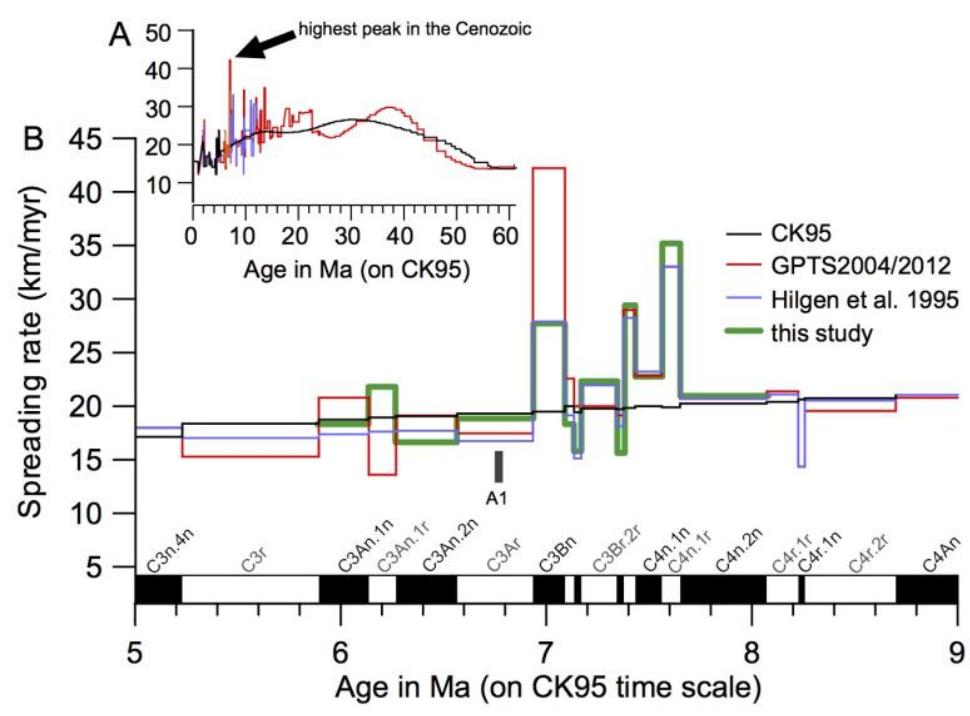

Figure 7. South Atlantic spreading rates calculated using the U1337, H95 (Hilgen et al., 1995) and GPTS2004/2012 (Lourens et al., 2004; Hilgen et al., 2012) for the (A) Cenozoic and (B) the interval from 9-5 Ma (adapted from Westerhold et al., 2012 to include rates calculated using the U1337 magnetostratigraphy). GPTS 2004 is equivalent to the GPTS2012 for the interval between 6-8 Ma. 


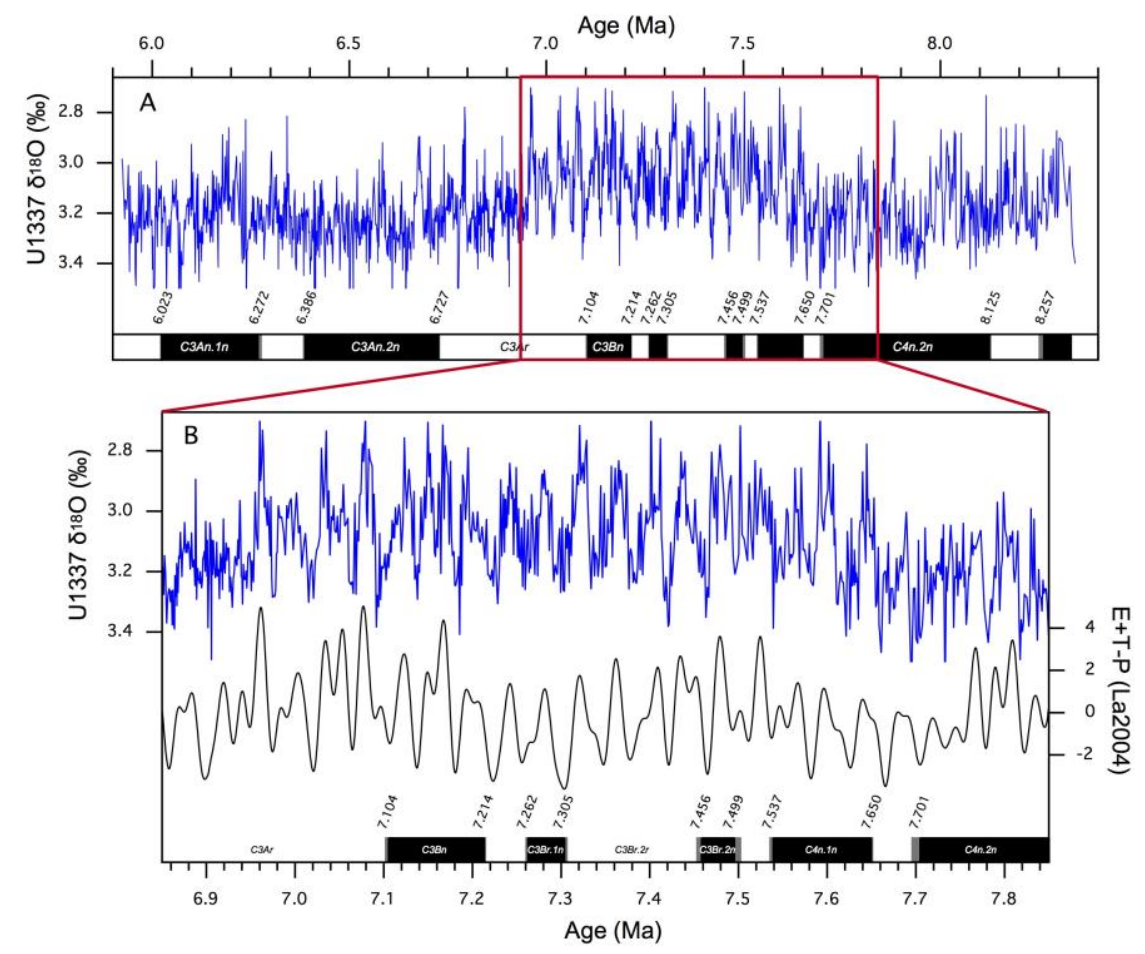

Figure 8. A) High-resolution U1337 benthic foraminiferal $\delta^{18} \mathrm{O}$ (in \%o versus VPDB) and B) close-up of the 6.9-7.7 Ma distinct $\delta^{18} \mathrm{O}$ cycles, indicative of high-latitude climate forcing, plotted together with the Eccentricity+Tilt-Precession tuning target (E+T-P) from La2004 (Laskar et al., 2004). 